\title{
Pengaruh Penggunaan Multimedia Terhadap Pemahaman Konsep \\ Pada Mata Kuliah Pengembangan Kognitif dan Kreatifitas Anak Usia Dini Di UNSRI Palembang
}

\author{
Hasmalena, ${ }^{1}$ Rukiyah $^{2}$, Mahyumi Rantina, ${ }^{3}$ \\ Program Studi PG-PAUD, Fakultas Keguruan dan Ilmu Pendidikan, Universitas Sriwijaya
}

\begin{abstract}
Abstrak
Pengaruh penggunaan multimedia terhadap pemahaman konsep mahasiswa PG-PAUD pada mata kuliah pengembangan kognitif dan kreatifitas anak usia dini, telah dilakukan pada mahasiswa PGPAUD semester tiga di Palembang universitas Sriwijaya. Jenis penelitian yang digunakan adalah eksperimen dengan desian One Shoot Case Study, dengan teknik pengambilan sampel yaitu purposive sampling. Sampel pada kelas pre-eksperimen berjumlah 27 dan pada kelas post-test berjumlah 28 . Teknik pengumpulan data berupa tes tertulis yang berbentuk essay, wawancara dan dokumentasi. Hasil analisis data yang diperoleh adalah 80,71 , sedangkan hasil pengujian hipotesis berdasarkan uji-t diperoleh $t_{\text {hitung }}>t_{\text {tabel }}$ atau didapat $t_{\text {hitung }}=6,76>t_{\text {tabel }}=4,83$, maka Ho ditolak dan Ha diterima, dengan demikian terdapat pengaruh penggunaan multimedia terhadap pemahaman konsep mahasiswa PG-PAUD pada mata kuliah pengembangan kognitif dan kreatifitas anak usia dini. Dengan indikator penilaian Menyatakan ulang sebuah konsep, Mengklasifikasi objek menurut sifat tertentu sesuai dengan konsepnya, Memberi contoh dari konsep, Menggunakan, memanfaatkan dan memilih prosedur tertentu. Jadi penggunaan multimedia terhadap pemahaman konsep pada mahasiswa sangat berpengaruh untuk meningkatkan pemahaman konsep.
\end{abstract}

Kata Kunci: Penggunaan Multimedia, Pemahaman Konsep, Anak Usia Dini

\begin{abstract}
The influence of multimedia usage on PG-PAUD student concept understanding in cognitive development and creativity course of early childhood has been done on PG-PAUD Student semester three in Palembang Sriwijaya University. The type of research used is experiment with One Shoot Case Study descriptions, with sampling technique that is purposive sampling. The sample in the preexperiment class is 27 and the post-test class is 28. The data collection technique is written essay, interview and documentation. Result of data analysis obtained is 80,71, while result of hypothesis test based on $t$-test obtained t_hitung $>$ t_table or got t_count $=6,76>t$ t_table $=4,83$, hence Ho refused and Ha accepted, thus there influence multimedia usage to understanding the concept of PG-Paud students in courses of cognitive development and creativity of early childhood. With assessment indicators Redefining a concept, Classifying objects according to certain traits according to their concepts, Providing examples of concepts, Using, utilizing and selecting specific procedures. So the use of multimedia to understanding the concept of the students is very influential to improve understanding of the concept.
\end{abstract}

Keywords: Multimedia Usage, Conceptual Understanding, Early Childhood Education

@ Jurnal Obsesi Prodi PG-PAUD FIP UPTT 2018

$\triangle$ Corresponding author : Hasmalena

Address : Jl. Palembang-Prabumulih, KM. 32 Indehralaya Ogan Ilir

Email : lena.bunda@yahoo.co.id

ISSN 2356-1327 (Media Cetak)

Phone : 081234866995

ISSN 2549-8959 (Media Online) 
86 | Pengaruh Penggunaan Multimedia Terhadap Pemahaman Konsep Pada Mata Kuliah Pengembangan Kognitif dan Kreatifitas Anak Usia Dini Di UNSRI Palembang

\section{PENDAHULUAN}

Multimedia adalah penggunaan
komputer untuk menyajikan dan menggabungkan teks, suara, gambar, animasi, audio, dan video dengan alat bantu (tool) dan koneksi (link) sehingga pengguna dapat melakukan navigasi, berinteraksi, berkarya dan berkomunikasi. Sedangkan Menurut Arsyad (2013:141), " multimedia adalah media berupa alat-alat audiovisual yang audible artinya dapat di dengar dan dan alat yang visible artinya dapat di lihat. Alat -alat berupa audiovisual gunanya untuk membuat cara berkomunikasi menjadi efektif. Media audiovisual merupakan bentuk media pengajaran yang terjangkau selanjutnya Kustiono berpendapat bahwa media pembelajaran seperti audiovisual merupakan bentuk dari media baik software maupun hardware yang mampu menyampaikan pesanpesan pembelajaran secara auditif sekaligus visual artinya pesan-pesan yang disampaikan melalui saluran indra pendengar dan penglihatan sekaligus (Kustiono 2011:78). Media audiovisual adalah media yang mempunyai unsur suara dan unsur gambar (Daryanto 2013:46). Selain itu, Menurut Priyono (2015), bahwa media adalah perantara atau pengantar pesan dari pengirim pesan kepada penerima pesan, terkait dengan pembelajaran media adalah segala sesuatu yang dapat digunakan untuk menyampaikan pesan dari pengirim pesan kepada penerima pesan sehingga dapat merangsang pikiran, perasaan dan perhatian peserta didik untuk tercapainya tujuan pembelajaran.

Berdasarkan uraian diatas yang dimaksud dengan penggunaan multimedia dalam penelitian ini adalah penggunaan media yang melibatkan beberapa fungsi baik melalui pendengaran dan visual juga media yang dapat mempengaruhi pikiran dan perhatian anak didik untuk mencapai tujuan seperti: pembuatan ppt dan pembuatan video animasi dalam pembelajaran.

Fungsi media pembelajaran menurut Sutikno (2013) adalah sebagai berikut:

1.Menarik perhatian siswa

2.Membantu untuk mempercepat pemahaman dalam proses pembelajaran

3. Memperjelas penyajian pesan agar tidak bersifat verbalistis

4.Mengatasi keterbatasan ruang

5.Pembelajaran lebih komunikatif dan produktif

6. Waktu pembelajaran bisa dikondisikan
7.Menghilangkan kebosanan siswa dalam belajar

8. Melayani gaya belajar siswa yang beraneka ragam dan

9. Meningkatkan kadar keaktifan atau keterlibatan siswa dalam kegiatan pembelajaran.

Pemahaman adalah kemampuan seseorang untuk mengerti atau memahami sesuatu. Dengan kata lain, memahami adalah mengetahui tentang sesuatu dan dapat melihatnya dalam berbagai segi. Seseorang dikatakan memahami suatu hal apabila ia dapat memberikan penjelasan dan meniru hal tersebut dengan menggunakan kata-katanya sendiri. Winkel (2004:274) mengemukakan bahwa pemahaman menacakup kemampuan untuk menangkap makna dan arti dari bahan yang dipelajari.

Bloom dalam Yunus (2009) menjelaskan bahwa pemahaman adalah suatu kemampuan untuk menyeraparti dari materi atau bahan yang dipelajari. Pemahaman merupakan jenjang kognitif $\mathrm{C}$ yang dalam bahasa disebut Comprehension. Selain itu, Arifin(2003) menjelaskan pemahaman adalah suatu kemampuan yang dimiilki siswa untuk mengubah, mengadakan interpretasi dan mengeksplorasi. Dari beberapa penjelasan diatas dapat disimpulkan bahwa pemahaman merupakan hasil proses belajar mengajar yang ditandai kemampuan menjelaskan atau mendefinisikan suatu informasi dengan katakata sendiri. Pemahaman merupakan kemampuan untuk menerangkan dan menginterprestasikan sesuatu.Pemahaman bukan sekedar mengetahui, yang biasanya hanya sebatas mengingat kembali pengalaman dan memproduksi apa yang pernah dipelajari. Pemahaman lebih dari sekedar mengetahui, karena pemahaman melibatkan proses mental yang dinamis. Pemahaman merupakan suatu proses bertahap yang mempunyai kemampuan tersendiri seperti menerjemahkan, menginterprestasi, eksplorasi,aplikasi, analisis, sintesis, dan evaluasi.

Konsep menurut Umar (2004:51)

konsep adalah sejumlah teori yang berkaitan dengan suatu objek. Konsep diciptakan dengan menggolongkan dan mengelompokkan objekobjek tertentuyang mempunyai ciri yang sama. Sedangkan menurut Soedjadi yang dikutip oleh Saifuddin (2014:67) konsep merupakan ide abstrak yang bisa digunakan untuk mengadakan klasifikasi ataupun penggolongan yang pada 
umumnya dinyatakan dengan suatu istilah maupun rangkaian kata. Berdasarkan pengertian diatas dapat disimpulkan bahwa konsep merupakan suatu ide abstrak dengan sejumlah teori yang berkaitan objek dan klasifikasi dinyatakan dengan rangkaian kata.

\section{METODE PENELITIAN}

Metode penelitian yang digunakan dalam penelitian ini adalah metode Preexperimental design dengan rancangan OneShot-Case-Study (Sugiyono, 2015:110). Penelitian eksperimen menurut Darmadi (2014:217) adalah satu-satunya metode penelitian yang dapat menguji hipotesis hubungan sebab-akibat. Senada dengan pendapat ahli di atas menurut Sugiono (2015:107) penelitian eksperimen dapat diartikan sebagai metode penelitian yang digunakan untuk mencari pengaruh perlakuan tertentu terhadap yang lain dalam kondisi yang terkendalikan. Jadi berdasarkan pendapat para ahli di atas dapat dikatakan bahwa penelitian eksperimen adalah metode penelitian yang menguji hipotesis sebab akibat yang digunakan untuk mencari pengaruh perlakuan tertentu.

\section{Variabel Penelitian}

Variabel penelitian menurut Sugiyono (2015:60) adalah segala sesuatu yang berbentuk apa saja yang ditetapkan oleh peneliti untuk dipelajari sehingga diperoleh informasi tentang hal tersebut, kemudian ditarik kesimpulannya. Menurut Arikunto (2010:161) variabel penelitian adalah objek penelitian atau apa yang menjadi titik perhatian suatu penelitian. Sedangkan menurut Selegi (2013:49) variabel adalah karakteristik yang akan diobservasi dari suatu pengamatan.

Berdasarkan dari uraian di atas maka dapat dikatakan bahwa variabel penelitian adalah objek penelitian yang berbentuk apa saja yang ditetapkan oleh peneliti yang menjadi titik perhatian suatu penelitian yang akan diobservasi dan dipelajari kemudian ditarik kesimpulannya. Adapun yang menjadi variabel dalam penelitian ini adalah :

1) Variabel bebas ( $x)$ : Penerapan Multimedia

2) Variabel terikat (y) : Kemampuan Mahasiswa PG PAUD

Tempat penelitian ini di Prodi PGPAUD Jurusan Ilmu Pendidikan Fakultas Keguruan dan Ilmu Pendidikan Kampus PGSD $\mathrm{Km}$ 5,5 Palembang. Waktu penelitian dilaksanakan pada mahasiswa semester 3 Tahun 2017.Populasi dalam penelitian ini adalah seluruh mahasiswa PG PAUD semester 3
Palembang tahun 2017, yang terdiri dari 28 mahasiswa.

Tabel 2.1 Populasi Penelitian

\begin{tabular}{|c|c|}
\hline Kelas & Jumlah Mahasiswa \\
\hline $\begin{array}{l}\text { Mahasiswa PG. PAUD } \\
\text { semester } 3 \text { Palembang } \\
\text { tahun } 2017\end{array}$ & 28 \\
\hline
\end{tabular}
digunakan adalah mahasiswa semester 3 tahun 2017 yang berjumlah 30 mahasiswa, yang terdiri dari 28 perempuan dan 2 laki-laki, yang berkaitan dengan mata kuliah Pengembangan Kognitif dan Kreatifitas AUD,teknik pengambilan sampel mengggunakan "Purposive Sampling".

Prosedur penelitian terdiri dari tiga tahap yaitu:

1) Tahap Persiapan

a) Melakukan penelitian dengan mewawancarai mahasiswa semester 3 tahun 2017

b) Membuat silabus dan perangkat perkuliahan

c) Menyiapkan Camera dan Handycame untuk pembuatan video pembelajaran menggunakan multimedia

d) Menyusun instrumen penelitian (kisikisi soal) diserta kunci jawaban dan pedoman penskoran

e) Menyiapkan alat peraga seperti Infocus

f) Melakukan validasi perangkat pembelajaran dan Instrumen penelitian

g) Mengujicobakan Instrumen dan Tes

2) Tahap pelaksanaan

Menentukan sampel penelitian dengan mengadakan eksperimen dengan desain one shot case study, yakni pertama memberi perlakuan (treatment) yaitu kelompok eksperimen (kelas sampel).

3) Tahap akhir (pengelolaan data)

a) Menskor hasil post-test

b) Mengkonversikan skor menjadi nilai

Tabel 2.2 Instrumen Pemahaman Konsep

\begin{tabular}{|c|l|c|c|c|c|}
\hline No & \multicolumn{1}{|c|}{ Aspek yang diamati } & \multicolumn{4}{|c|}{ Skor } \\
\cline { 3 - 6 } & & 1 & 2 & 3 & 4 \\
\hline 1. & $\begin{array}{l}\text { Menyatakan ulang sebuah } \\
\text { konsep }\end{array}$ & & & & \\
\hline 2. & $\begin{array}{l}\text { Mengklasifikasi objek } \\
\text { menurut sifat tertentu sesuai } \\
\text { dengan konsepnya }\end{array}$ & & & & \\
\hline 3. & Memberi contoh dari konsep & & & & \\
\hline 4. & $\begin{array}{l}\text { Menggunakan, memanfaatkan } \\
\text { dan memilih prosedur tertentu }\end{array}$ & & & & \\
\hline 5. & Mengaplikasikan konsep & & & & \\
\hline
\end{tabular}


88 | Pengaruh Penggunaan Multimedia Terhadap Pemahaman Konsep Pada Mata Kuliah Pengembangan Kognitif dan Kreatifitas Anak Usia Dini Di UNSRI Palembang

\section{Teknik Analisis Data}

Teknik Analisis data yang akan digunakan dalam penelitian ini adalah uji statistik paramtrik $\mathrm{t}$ (uji-t). Uji statistik digunakan untuk menguji penolakan atau penerimaan hipotesis nol, dengan syarat bahwa sampel itu homogen dan berdistribusi normal. Nilai dari hasil tes yang diperoleh pada kelas ekperimen dan kelas kontrol disusun dalam tabel distribusi frekuensi. Dalam penelitian ini menggunakan uji normalitas data dan uji hipotesis. Setelah mendapatkan nilai selanjutnya menentukan kriteria sesuai dengan nilai yang didapat.

Tabel 2.3 Konversi Skor

\begin{tabular}{|c|c|c|}
\hline Angka & Huruf & Keterangan \\
\hline $85-100$ & A & Amat baik \\
\hline $71-84$ & B & Baik \\
\hline $60-70$ & C & Cukup \\
\hline $50-59$ & D & Kurang \\
\hline$<49$ & E & Kurang Sekali \\
\hline
\end{tabular}

\section{Uji Hipotesis}

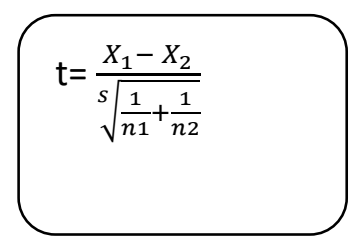

(Sudjana, 2009:239)

\section{HASIL DAN PEMBAHASAN}

Pada penelitian ini peneliti menggunakan rata-rata tes sebelum perlakuan yang dilihat dari nilai penugasan mahaiswa semester 3 PG. PAUD 2017 Palembang. Didapat nilai rata-rata dan nilai standar deviasi untuk setiap indikator yang dapat dilihat pada tabel.

Tabel 3.1 Data Nilai Rata-Rata Orang Mahasiswa Pada Setiap Indikator

\begin{tabular}{|c|c|c|c|}
\hline Kelas & $\begin{array}{c}\text { Nilai } \\
\text { Tertinggi }\end{array}$ & $\begin{array}{c}\text { Nilai } \\
\text { Terendah }\end{array}$ & $\begin{array}{c}\text { Rata- } \\
\text { rata }\end{array}$ \\
\hline $\begin{array}{c}\text { Pre } \\
\text { test }\end{array}$ & 80 & 45 & 63 \\
\hline
\end{tabular}

Data dari penelitian ini adalah rata-rata posttest. Posttest ini dilakukan untuk melihat pengaruh penggunaan multimedia terhadap pemahaman konsep mahasiswa PG. PAUD semester 3 pada matakuliah pengembangan kognitif dan kretivitas anak usia dini di Palembang.

Tabel 3.2 Distribusi Frekuensi Pemahaman Konsep

\begin{tabular}{|c|c|c|c|}
\hline Kategori & $\begin{array}{c}\text { Rentang } \\
\text { Nilai }\end{array}$ & Frekuensi & Persentase \\
\hline A & $\begin{array}{c}85- \\
100\end{array}$ & 11 & $39 \%$ \\
\hline B & $71-84$ & 12 & $43 \%$ \\
\hline C & $60-70$ & 5 & $18 \%$ \\
\hline D & $50-59$ & - & - \\
\hline E & $<49$ & - & - \\
\hline
\end{tabular}

Pada penelitian ini banyak sampel terdiri dari 28 mahasiswa pada semester 3 Palembang. Peneliti menganalisis nilai pre-test mahasiswa terhadap pemahaman konsep mahasiswa dengan mencari nilai rata-rata. Terdapat rata-rata skor sebelum perlakuan. Berikut ini perbedaan signifikan hasil pre test dan post test yang terlihat pada tabel berikut ini:

Tabel 3.3 Hasil Pre Test Dan Posttest

\begin{tabular}{|c|c|c|c|c|}
\hline No & Kelas & $\begin{array}{c}\text { Nilai } \\
\text { Tertinggi }\end{array}$ & $\begin{array}{c}\text { Nilai } \\
\text { Terendah }\end{array}$ & $\begin{array}{c}\text { Rata- } \\
\text { rata }\end{array}$ \\
\hline 1. & $\begin{array}{c}\text { Pre } \\
\text { test }\end{array}$ & 80 & 45 & 63 \\
\hline 2. & $\begin{array}{c}\text { Post } \\
\text { test }\end{array}$ & 95 & 60 & 80 \\
\hline
\end{tabular}

\section{Uji Normalitas Data Pre-Test}

Hasil pre-test yang diperoleh mahasiswa yang telah ditetapkan oleh dosen matakuliah perkembangan kognitif dan kreativitas dapat dilihat paada tabel berikut.

Tabel 3.4 Kriteria Hasil Belajar Siswa

\begin{tabular}{|c|c|c|}
\hline Angka & Huruf & Keterangan \\
\hline $85-100$ & A & Amat baik \\
\hline $71-84$ & B & Baik \\
\hline $60-70$ & C & Cukup \\
\hline $50-59$ & D & Kurang \\
\hline$<49$ & E & Kurang Sekali \\
\hline
\end{tabular}

Mahasiswa yang mendapatkan nilai 85 - 95 dengan kriteria "Amat Baik" tidak didapatkan oleh mahasiswa, kemudian mahasiswa yang mendapatkan nilai $71-84$ dengan kriteria "Baik" sebanyak 2 orang mahasiswa, selanjutnya mahasiswa yang mendapatkan nilai $60-70$ dengan kritria "Cukup" sebanyak 19 orang mahasiswa, sedangkan dengan kriteria "kurang" dengan rentang nilai 50 - 59 sebanyak 5 mahasiswa ,1 
mahasiswa mendapatkan kriteria "Kurang Sekali" . dari jumlah mahasiswa sebanyak 30 orang didapatkan nilai tertinggi 83 dan nilai terendah 0 dengan rata-rata 74 . Dari data hasil tes kelas eksperimen tersebut, maka perlu dibuat satu rentang (interval) untuk mempermudah memasukkan data ke simpangan baku.

Nilai tertinggi : 80

Nilai terendah : 45
a. Rentang = nilai terbesar - nilai terendah $=80-45=35$

b. Banyak kelas interval

$=1+3,3 \log \mathrm{n}$

$=1+3,3 \log 27$

$=1+3,3(1,43)$

$=5,71$ yang dibulatkan menjadi 6

Jadi, panjanng kelas interval yang diambil 6 (enam) kelas.

Panjang kelas interval $=\frac{\text { rentang kelas }}{\text { banyak kelas }}$ $=\frac{35}{6}=5,83$ dibulatkan menjadi 6

Jadi, panjang kelas interval yang diambil adalah 6

c. Tabel distribusi frekuensi

Tabel 3.5 Distribusi Frekuensi Nilai Pre Test

\begin{tabular}{|c|c|c|c|c|c|}
\hline $\begin{array}{c}\text { Interv } \\
\text { al }\end{array}$ & $\boldsymbol{f}_{\boldsymbol{i}}$ & $\boldsymbol{X}_{\boldsymbol{i}}$ & $\boldsymbol{f}_{\boldsymbol{i}} \cdot \boldsymbol{X}_{\boldsymbol{i}}$ & $\boldsymbol{X}_{\boldsymbol{i}}{ }^{\mathbf{2}}$ & $\boldsymbol{f}_{\boldsymbol{i}} \cdot \boldsymbol{X}_{\boldsymbol{i}}^{\mathbf{2}}$ \\
\hline $45-$ & 2 & 47, & 95 & 2256, & 4512,5 \\
50 & & 5 & & 25 & \\
\hline $51-$ & 4 & 53, & 214 & 2862, & 11449 \\
56 & & 5 & & 25 & \\
\hline $57-$ & 7 & 59, & 416, & 3540, & 24781,7 \\
62 & & 5 & 5 & 25 & 5 \\
\hline $63-$ & 5 & 65, & 327, & 4290, & 21451,2 \\
68 & & 5 & 5 & 25 & 5 \\
\hline $69-$ & 6 & 71, & 429 & 5112, & 30673,5 \\
74 & & 5 & & 25 & \\
\hline $75-$ & 3 & 77, & 232, & 6006, & 169937, \\
80 & & 5 & 5 & 25 & 1 \\
\hline Jumla & $\mathbf{2}$ & $\mathbf{3 7}$ & $\mathbf{1 7 1 4}$ & $\mathbf{2 4 0 6 7}$ & $\mathbf{1 1 0 8 8 6}$, \\
$\mathbf{h}$ & $\mathbf{7}$ & $\mathbf{5}$ & $\mathbf{5}$ & $\mathbf{5}$ & $\mathbf{7 5}$ \\
\hline
\end{tabular}

Dari tabel distribusi frekuensi di atas dapat dilihat bahwa frekuensi dari tiap-tiap kelas interval yang memiliki frekuensi $\left(f_{i}\right)$ terdapat paling banyak dalam kelas $57-62$ sebanyak 7 mahasiswa, sedangkan untuk kelas terendah 45 - 50 sebanyak 2 mahasiswa.

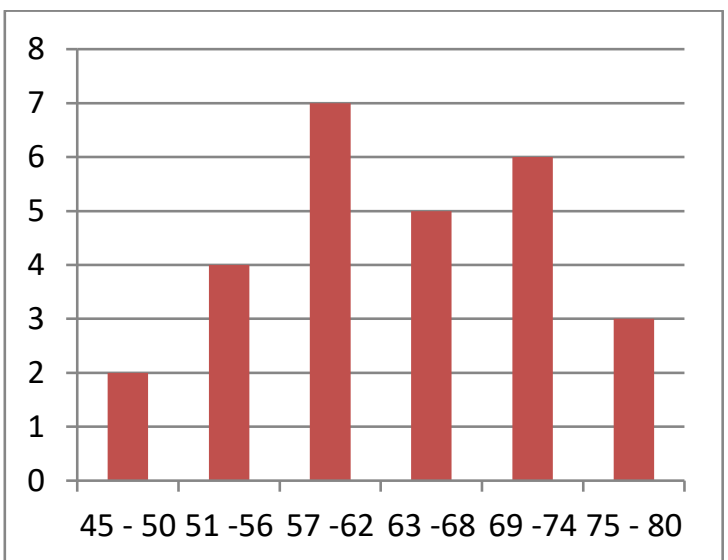

Gambar grafik distribusi frekuensi nilai pre test

d. Nilai rata-rata kelas eksperimen

$$
\begin{aligned}
\bar{X} & =\frac{\sum f i . X i}{\sum f i} \\
& =\frac{1714,5}{27} \\
& =63,5
\end{aligned}
$$

e. Modus

$$
\begin{aligned}
\text { Mo } & =b+p\left[\frac{b 1}{b i+b 2}\right] \\
& =56,5+6\left[\frac{3}{3+2}\right] \\
& =56,5+3,6 \\
& =60,1
\end{aligned}
$$

f. Simpangan baku

$$
\begin{aligned}
S^{2} & =\frac{n \sum f i x i^{2}-\left(\sum f i x i\right)^{2}}{n(n-1)} \\
& =\frac{27(110886,75)-(1714,5)^{2}}{27(27-1)} \\
& =\frac{2993942,25-2939510,25}{27(26)} \\
& =\frac{54432}{702} \\
S^{2} & =77,53 \\
S & =\sqrt{77,53} \\
S & =8,80
\end{aligned}
$$

Dari rata-rata, modus, dan simpangan baku dapat dicari koefisien kemiringan kurva dengan menggunakan rumus Karl Pearson, yaitu:

$$
\begin{aligned}
\mathrm{Km} & =\left[\frac{\bar{X}-M o}{S}\right] \\
& =\left[\frac{63,5-60,1}{8,80}\right] \\
& =\left[\frac{3,4}{8,80}\right] \\
& =0,38
\end{aligned}
$$

Berdasarkan perhitungan data di atas, maka nilai $\mathrm{Km}$ adalah 0,38 karena nilai $\mathrm{Km}$ sebesar 0,38 dan harga ini terletak antara (-1) dan (1), maka data kelas pre-test dapat dikatan berdistribusi normal.

\section{Uji Normalitas Data Post-Test}

Hasil pre-test yang diperoleh mahasiswa yang telah ditetapkan oleh dosen matakuliah perkembangan kognitif dan kreativitas. 
90 | Pengaruh Penggunaan Multimedia Terhadap Pemahaman Konsep Pada Mata Kuliah Pengembangan Kognitif dan Kreatifitas Anak Usia Dini Di UNSRI Palembang

mahasiswa yang mendapatkan nilai 85 - 95 dengan kriteria "Amat Baik" sebanyak 11 mahasiswa, kemudian mahasiswa yang mendapatkan nilai $71-84$ dengan kriteria "Baik" sebanyak 12 orang mahasiswa, selanjutnya mahasiswa yang mendapatkan nilai 60 - 70 dengan kritria "Cukup" sebanyak 5 orang mahasiswa. Dari jumlah mahasiswa sebanyak 28 orang didapatkan nilai tertinggi 95 dan nilai terendah 60 dengan rata-rata 80. Dari data hasil tes kelas eksperimen tersebut, maka perlu dibuat satu rentang (interval) untuk mempermudah memasukkan data ke simpangan baku.

a. Rentang

$=$ nilai terbesar - nilai terendah

$=95-60=35$

b. Banyak kelas interval

$=1+3,3 \log n$

$=1+3,3 \log 28$

$=1+3,3(1,44)$

$=5,75$ yang dibulatkan menjadi 6

Jadi, panjanng kelas interval yang diambil 6 (enam) kelas.

c. Panjang kelas interval

$$
\begin{aligned}
& =\frac{\text { rentang kelas }}{\text { banyak kelas }} \\
& \quad=\frac{35}{6}=5,83 \text { dibulatkan menjadi } 6
\end{aligned}
$$

Jadi, panjang kelas interval yang diambil 6 .

d. Tabel distribusi frekuensi

Tabel 3.6 Distribusi Frekuensi Nilai Pre

Test

\begin{tabular}{|c|c|c|c|c|c|}
\hline $\begin{array}{c}\text { Interv } \\
\text { al }\end{array}$ & $\boldsymbol{f}_{\boldsymbol{i}}$ & $\boldsymbol{X}_{\boldsymbol{i}}$ & $\begin{array}{c}\boldsymbol{f}_{\boldsymbol{i}} \cdot \\
\boldsymbol{X}_{\boldsymbol{i}}\end{array}$ & $\boldsymbol{X}_{\boldsymbol{i}}{ }^{\mathbf{2}}$ & $\boldsymbol{f}_{\boldsymbol{i}} \cdot \boldsymbol{X}_{\boldsymbol{i}}{ }^{\mathbf{2}}$ \\
\hline $60-$ & 3 & 62, & 187, & 3906,2 & 11718, \\
65 & & 5 & 5 & 5 & 75 \\
\hline $66-$ & 2 & 68, & 137 & 4692,2 & 9384,5 \\
71 & & 5 & & 5 & \\
\hline $71-$ & 4 & 74, & 298 & 5550,2 & 22201 \\
77 & & 5 & & 5 & \\
\hline $78-$ & 8 & 80, & 644 & 6480,2 & 51842 \\
83 & & 5 & & 5 & \\
\hline $84-$ & 4 & 86, & 346 & 7482,2 & 29929 \\
89 & & 5 & & 5 & \\
\hline $90-$ & 7 & 92, & 647, & 8556,2 & 59893, \\
95 & & 5 & 5 & 5 & 75 \\
\hline $\begin{array}{c}\text { Jumla } \\
\mathbf{h}\end{array}$ & $\mathbf{2}$ & $\mathbf{4 6}$ & $\mathbf{2 2 6}$ & $\mathbf{3 6 6 6 7}$, & $\mathbf{1 8 4 9 6 9}$ \\
$\mathbf{0}$ & $\mathbf{5}$ & \\
\hline
\end{tabular}

Dari tabel distribusi frekuensi di atas dapat dilihat bahwa frekuensi dari tiap-tiap kelas interval yang memiliki frekuensi $\left(f_{i}\right)$ terdapat paling banyak dalam kelas $78-83$ sebanyak 8 mahasiswa, sedangkan untuk kelas terendah $66-71$ sebanyak 2 mahasiswa.

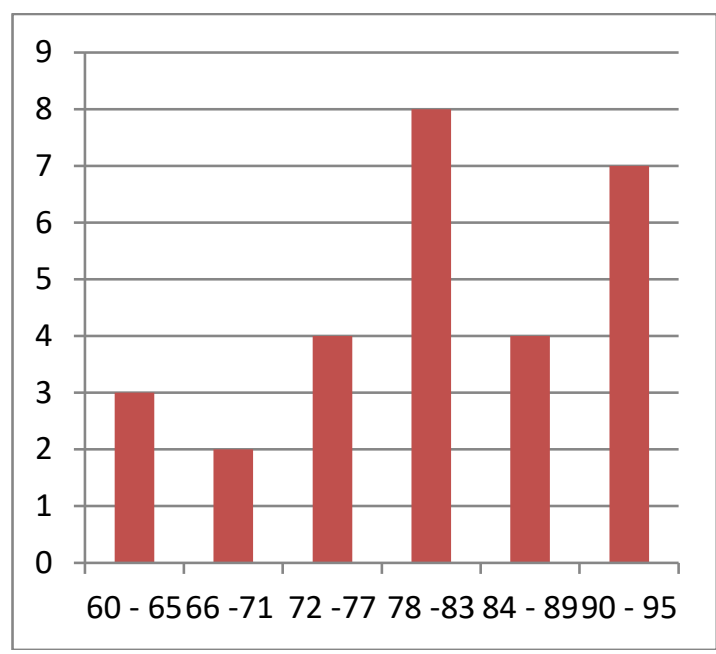

Gambar grafik distribusi frekuensi nilai posttest

e. Nilai rata-rata kelas eksperimen

$$
\begin{aligned}
\bar{X} & =\frac{\sum f i . X i}{\sum f i} \\
& =\frac{2260}{28} \\
& =80,71
\end{aligned}
$$

f. Modus

$$
\begin{aligned}
\text { Mo } & =\mathrm{b}+\mathrm{p}\left[\frac{b 1}{b i+b 2}\right] \\
& =77,5+6\left[\frac{4}{4+4}\right] \\
& =77,5+6\left[\frac{4}{8}\right] \\
& =77,5+3 \\
& =80,5
\end{aligned}
$$

g. Simpangan baku

$$
\begin{aligned}
S^{2} & =\frac{n \sum f i x i^{2}-\left(\sum \text { fixi }\right)^{2}}{n(n-1)} \\
& =\frac{28(184969)-(2260)^{2}}{28(28-1)} \\
& =\frac{5179132-5107600}{28(27)} \\
& =\frac{71532}{756} \\
S^{2} & =94,61 \\
S & =\sqrt{94,61} \\
S & =9,72
\end{aligned}
$$

Dari rata-rata, modus, dan simpangan baku dapat dicari koefisien kemiringan kurva dengan menggunakan rumus Karl Pearson, yaitu:

$$
\begin{aligned}
\mathrm{Km} & =\left[\frac{\bar{X}-M o}{S}\right] \\
& =\left[\frac{80,71-80,5}{9,72}\right] \\
& =\left[\frac{0,21}{9,72}\right] \\
& =0,021
\end{aligned}
$$

Berdasarkan perhitungan data di atas, maka nilai $\mathrm{Km}$ adalah 0,021 karena nilai $\mathrm{Km}$ sebesar 0,021 dan harga ini terletak antara (-1) dan (1) , maka data kelas pre-test dapat dikatan berdistribusi normal. 


\section{Perumusan hipotesis}

Langkah-lagkah yang peneliti lakukan dalam mengambil kesimpulan dari hipotesis adalah sebagai berikut: Berdasarkan perumusan hipotesis, yaitu:

$H_{0}$ : tidak ada pengaruh penggunaan multimedia terhadap pemahaman konsep mahasiswa PG. PAUD pada matakuliah pengembangan kognitif dan kreativitas anak usia dini di UNSRI Palembang.

$H_{a}$ : ada pengaruh penggunaan multimedia terhadap pemahaman konsep mahasiswa PG. PAUD pada matakuliah pengembangan kognitif dan kreativitas anak usia dini di UNSRI Palembang.

\section{Menentukan $\boldsymbol{t}_{\text {hitung }}$}

Setelah menghitung nilai rata-rata dan standar deviasi mahasiswa selanjutnya melakukan perhitungan uji-t. Untuk mendapatkan nilai $X_{1}$ menggunakan nilai pre-test setelah itu diperoleh hasil nilai rata-rata dan standar devisiasi. Kemudian membandingkan nilai rata-rata dan standar devisiasi posttest.

a. Perhitungan uji-t

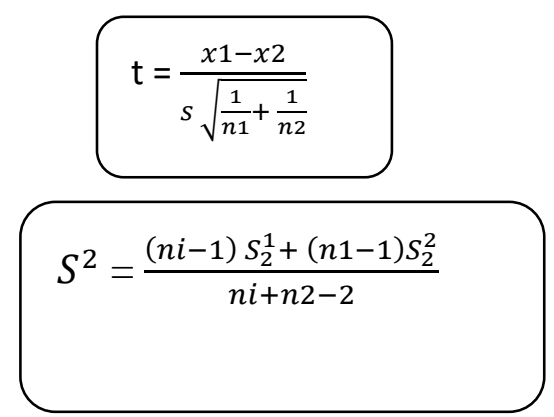

Tabel 3.7

Nilai Rata-Rata Dan Simpangan Baku

\begin{tabular}{|c|c|}
\hline Kelas Post-test & Kelas Pre-test \\
\hline $\bar{X}_{1}=80,71$ & $\bar{X}{ }^{2}=63,5$ \\
$S_{1}{ }^{2}=94,61$ & $S_{2}{ }^{2}=94,61$ \\
$n_{1}=28$ & $n_{2}=27$ \\
& \\
\hline
\end{tabular}

Dengan nilai yang terdapat pada tabel, maka dilakukan perhitungan sebagai berikut:

$$
\begin{aligned}
S^{2} & =\frac{(n i-1) S_{2}^{1}+(n 1-1) S_{2}^{2}}{n i+n 2-2} \\
& =\frac{(28-1) 94,61+(27-1) 86,23}{53} \\
& =\frac{2554,47+224,98}{53} \\
& =\frac{4796,45}{53} \\
S^{2} & =90,49 \\
S & =\sqrt{90,49} \\
S & =9,51
\end{aligned}
$$

Kemudian $t_{\text {hitung }}$ dicari dengan rumus:

$$
\begin{aligned}
& \mathrm{t}=\frac{x 1-x 2}{\sqrt[s]{\frac{1}{n 1}+\frac{1}{n 2}}} \\
& =\frac{80,71-63,5}{\sqrt[9,51]{\frac{1}{28}+\frac{1}{27}}} \\
& =\frac{16,71}{9,51} \sqrt{\frac{1}{28}+\frac{1}{27}} \\
& =\frac{16,71}{\sqrt[9,51]{0,072}} \\
& =\frac{16,71}{9,51 \times 0,26} \\
& =\frac{16,71}{2,47} \\
& t_{\text {hitung }}=6,76
\end{aligned}
$$

b. Menentukan $t_{\text {tabel }}$

Mencari $t_{\text {tabel }}$ untuk $\mathrm{t}(1-a)$ adalah:

$$
\begin{aligned}
\mathrm{dk} & =n_{1}+n_{2}-2 \\
& =28+27-2 \\
\mathrm{dk} & =53
\end{aligned}
$$

untuk mengetahui $t_{\text {tabel }}$, karena tidak terdapat di dalam distribusi tabel dengan $\mathrm{dk}=\mathrm{n}-2=53$ dengan taraf kepercayaan $95 \%$ dihitung dengan rumus interpolasi sebagai berikut:

$\frac{60-(d k)}{(d k)-40}=\frac{t(0,95)(60)-x}{x-(0,95)(40)}$

$\frac{60-53}{53-40}=\frac{1,671-x}{x-1,684}$

$\frac{7}{13}=\frac{1,671-x}{x-1,684}$

$0,53 \mathrm{x}-0,89=1,671-\mathrm{x}$

$0,53 \mathrm{x}+\mathrm{x}=1,671+0,98$

$0,53 \mathrm{x}=2,561$

$\mathrm{X}=\frac{2,561}{0,53}=4,83$

Berdasarkan perhitungan data di atas, $t_{\text {tabel }}(0,95)$ diperoleh sebesar 4,83 sedangkan $t_{\text {hitung }} 6,76$ dengan taraf signifikansi 0,05 lebih besar dibandingkan dengan $t_{\text {tabel }} 4,83$ jadi, dari hasil perhitungan diperoleh 6,76> 4,83 dan hipotesis yang diterima adalah tolak Ho diterima Ha atau $t_{\text {hitung }}>t_{\text {tabel }}$. Akhirnya dapat disimpulkan bahwa ada pengaruh penggunaan multimedia terhadap pemahaman konsep mahasiswa PG-PAUD pada mata kuliah pengembangan kognitif dan kreatifitas anak usia dini di UNSRI Palembang.

\section{Pembahasan}

Peneliti menggunakan dua jenis tes yaitu pre-test dan post test. Jumlah siswa terdiri dari 28 pada pre-test dan 27 pada post-test jadi jika dijumlahkan total sampel adalah 55 mahasiswa semester 3 PG. Paud UNSRI Palembang. Proses dalam penelitian ini dilakukan sebanyak tujuh kali pertemuan. Pada kelas pre-test mahasiswa tidak di berikan perlakuan (treatment) sedangkan untuk kelas post-test diberikan perlakuan (treatment) berupa penggunaan multimedia terhadap pemahaman konsep mahasiswa pada mata 
kuliah kognitif dan kreativitas anak usia dini sebanyak tuju kali pertemuan. Pembelajaran pada kedua test tersebut dengan 3 SKS. Selanjutnya mahasiswa diberikan kesempatan untuk berdiskusi (presentasi) di dalam kelas dengan topik yang sama dengan kelas post-test yang telah diberikan perlakuan sebelumnya. Hasil test yang telah didaptkan dari masingmasing kelas dinilai berdasarkan rubrik dan indikator yang telah ditentukan. Nilai-nilai tersebut kemudian dianalisis atau diolah untuk memperoleh deskripsi tentang perbedaan peningkatan pemahaman konsep antar kelas yang diberikan perlakuan dan yang tidak diberikan perlakuan.

Pada post-test yang telah diberikan perlakuan berupa penggunaan multimedia terdapat pengaruh yang signifikan yang dapat dilihat dari perbedaan hasil tes mahasiswa antara nilai pre-test dan nilai post-test. Pada kelas pre-test yang berjumlah 27 mahasiswa dengan jumlah keseluruhan hasil test sebesar 1715 , nilai tertinggi yang didapatkan ialah 80 dan nilai terendah 45 , dengan rata-rata sebesar 63. Sedangkan untuk nilai post-test yang diberikan perlakuan (treatment) berupa penggunaan multimedia. Keseluruhan hasil test berjumlah 2250 dengan nilai rata-rata kelas sebesar 80 , nilai tertinggi yang didapatkan ialah 95 dengan nilai terendah sebesar 60 . Berdasarkan hasil perhitungan tersebut maka terdapat pengaruh kuantitatif yang signifikan antara ke dua nilai tersebut.

Sedangkan pengaruh kualitatif antara pre-test dan post-test yang dapat dilihat proses belajar mengajarnya. Penggunaan multimedia (treatment) dalam matakuliah perkembangan kognitif dan kreativitas pada kelas post-test terlihat bahwa motivasi belajar mereka tinggi dan antusias dalam proses pembelajaran meningkat, hal tersebut disebabkan oleh adanya perlakuan yang diberikan dalam hal ini adalah penggunaan multimedia pada setiap pertemuan, mahasiswa juga di biasakan untuk berperan aktif dalam proses pembelajaran di kelas. Mengingat banyak manfaat yang dari penggunaan multimedia itu sendiri. Mahasiswa lebih giat dan semangat dalam mengikuti perkuliahan. Sedangkan dari segi pemahaman konsep pada mahasiswa juga menunjukkan peningkatan, mahaiswa lebih memahami suatu topik pembelajaran dengan dibuktikan dari hasil nilai yang diperoleh. Selanjutnya pada kelas pre-test yang tidak diberikan perlakuan sebelumnya mendapatkan hasil yang sebaliknya yaitu motivasi dan semangat belajarnya tidak terlihat. Malah cenderung monoton. Hal ini dikarenakan kelas pre-test tidak mendapatkan perlakuan.

Setelah memperoleh hasil tes mahasiswa maka peneliti melakuan analisa terhadap hasil tes tersebut. Analisa yang telah dilakukan ialah menggunakan uji-t yang terdiri dari uji normalitas dan uji hipotesis. Berdasarkan hasil yang telah diperoleh pada kelas pre-test, uji normalitas yang didapat sebesar $\mathrm{Km}=0,38$ dan harga tersebut terletak antara (-1) dan (1) ssehingga dapat dikatakan bahwa data kelas kontrol dapat berdistribusi normal. Selanjutnya pada kelas post-test diperoleh $\mathrm{Km}=$ 0,21 dan harga tersebut terletak antara (-1) dan (1) sehingga dapat dikatakan kelas post-test berdistribusi normal.

Selanjutnya setelah diketahui bahwa seluruh data berdistribusi normal maka tahap selanjutnya adalah pengujian hipotesis dengan menunjukkan bahwa hasil tes akhir untuk kelas pos-test diperoleh $t_{\text {hitung }}=6,76$ dan $t_{\text {tabel }}$ dengan taraf kepercayaan $0.05 \mathrm{dan} \mathrm{dk}=$ 53 diperoleh $t_{\text {tabel }}=4,83$ dengan demikian $t_{\text {hitung }}>t_{\text {tabel }}$ jadi dapat dikatakan bahwa ada pengaruh penggunaan multimedia terhadap pemahaman konsep mahasiswa PG-PAUD pada mata kuliah pengembangan kognitif dan kreatifitas anak usia dini di UNSRI Palembang.

\section{SIMPULAN}

Berdasarkan hasil analisis dan pembahasan yang telah diperoleh oleh peneliti dari penelitian yang telah dilakukan, maka dapat diperoleh kesimpulan sebagai berikut:

1) Pemberian perlakuan berupa penggunaan multimedia merupakan media yang dapat mendorong minat belajar mahasiswa agar lebih giat dalam belajar serta antusias dalam mengikuti pembelajaran. Penggunaan multimedia dalam setiap pertemuan berpengaruh terhadapa pemahaman konsep mahasiswa pada matakuliah perkembangan kognitif dan kreativitas anak usia dini hal ini dapat dibuktikan dengan hasil rata-rata tes mahasiswa pada kelas pre-test adalah 63 pada kelas post-test sebesar 63 .

2) Setelah mendapatkan data hasil tes kemudian peneliti melakukan pengolahan data, maka didapatkan hasil perhitungan dengan $t_{\text {tabel }}=4,83$ sedangkan $t_{\text {hitung }}=$ 6,67 dengan taraf signifikan $0,05, t_{\text {hitung }}$ $=6,76$ lebih besar dibandingkan dengan $t_{\text {tabel }}=4,83$, jadi dari hasil perhitungan didapat $t_{\text {hitung }}=6,76>t_{\text {tabel }}=4,83$ maka dapat disimpulkan ada pengaruh 
penggunaan multimedia terhadap pemahaman konsep. Dengan demikian hipotesis alternatif (Ha) diterima dan hipotesis nol (Ho) di tolak.

\section{DAFTAR PUSTAKA}

Arikunto,Suharsimi,dkk. $2010 \quad$.Prosedur Penelitian Suatu Pendekatan Praktek, Jakarta : Rineka Cipta.

Arikunto,Suharsimi,dkk.2012.Prosedur

$$
\begin{aligned}
& \text { Penelitian Suatu Pendekatan } \\
& \text { Praktek,Jakarta : Rineka Cipta }
\end{aligned}
$$

Asyhar, Rayandr, 2012. Kreatif Mengembangkan Media Pembelajaran, Jakarta

Daryanto, 2013. Media Pembelajaran Peranannya sangat penting dalam mencapai Tujuan Pembelajaran, Jogyakarta:Gava media

Daryanto. 2012. Evaluasi Pendidikan. Jakarta: Rineka Cipta.

Faipri, Slegi.S.2013. Metodologi Penelitian Geografi. Palembang:Noerfikri.

Fauziddin, M. (2015). Peningkatan Kemampuan Klasifikasi melalui Media Benda Konkret pada Anak Kelompok A1 Di TK Cahaya Kembar Bangkinang Kampar.Jurnal Obsesi : Journal Of Early Childhood Education, 1(2), 1225. doi:10.31004/obsesi.v1i2.104

Gunawan, M.A. 2013. Statistik Untuk Penelitian Pendidikan. Yogyakarta:Parama Publishing.

Rukiyah, 2015. Pengembangan Model Pembelajaran Berbasis E-Learning dalam mata kuliah Pengembangan Kognitif dan Kreatifitas Anak Usia Dini.Laporan Penelitian Universitas Sriwijaya.

Sanjaya, W. 2013. Penelitian Pendidikan Jenis, Metode dan Prosedur. Jakarta: Kencana.

Sudjana.2009. Metoda Statistika. Bandung:Tarsito.

Sugiyono. 2012. Statistik Untuk Penelitian. Bandung: Alfabeta.

Sugiyono. 2015. Metode Penelitian Pendidikan Pendektan Kuantitatif, Kualitatif, Kualitas, dan R\&D. Bandung:Alfabeta.

Sutikno,Sobry (2013) Belajar dan Pembelajaran, Bandung:Prosfect
Umar, Husain.2004. Metode Riset Ilmu Administrasi. Jakarta:Gramedia Pustaka Utama. 